\title{
Petrographical and geochemical signatures of the Granja paragneisses (Médio Coreaú Domain, NW Ceará, Brasil)
}

\section{Características petrográficas y geoquímicas de los paragneises de Granja (Dominio Medio Coreaú, NW Ceará, Brasil)}

\author{
A.J.F. Silva', M.R. Azevedo', B. Valle Aguado ${ }^{1}$, J.A. Nogueira Neto ${ }^{2}$, T.J.S. Santos ${ }^{3}$, \\ F.D.O. Silva ${ }^{2}$ \\ 1 GeoBioTec, Departamento de Geociências, Universidade de Aveiro, 3810-193, Aveiro, Portugal. Email: antoniojsilva@ua.pt \\ 2 Departamento de Geologia, Universidade Federal do Ceará, Campus do Pici, Bloco 912 CEP 60455-760, Fortaleza, CE, Brasil \\ 3 Instituto de Geociências, Universidade Estadual de Campinas, 6152, CEP 13081-970, Campinas, SP, Brasil
}

\begin{abstract}
The Granja Granulite Complex (GGC) exposed in the Médio Coreaú Domain (NW Ceará, Brasil) consists mainly of garnet and sillimanite migmatitic paragneisses enclosing discontinuous lenses of mafic granulites and enderbites. According to the published geochronological data, this high-grade metamorphic belt represents a segment of the Paleoproterozoic basement intensely reworked during the Brasiliano / Pan-African Orogeny in the Neoproterozoic (600 Ma).

The Granja paragneisses are strongly foliated rocks characterized by the alternance of dark garnet-biotitesillimanite-rich layers and millimeter-thick leucocratic quartz-feldspathic bands, interpreted as indicative of incipient melting. As melt contents increase, layer-parallel leucosomes become thicker and a well-developed stromatic layering is defined. Both the gneissic and stromatic fabrics are strongly overprinted by a penetrative mylonitic foliation correlated to the last reactivation of the dextral NE-SW trending Granja Shear Zone (GCZ) that cuts across the studied area. Mineral assemblages and microstructures indicate that these rocks were affected by granulite-facies metamorphism and anatexis followed by decompression and cooling.

In order to constrain the protolith composition of the Granja paragneisses, twelve whole-rock samples from the parts of the migmatitic paragneisses that appear to have undergone little or no melt extraction were analysed for major and trace elements. In the classification diagram of Herron (1988), the samples plot in the transition between the greywacke and the pelite fields, suggesting that the pre-metamorphic sequence was dominantly composed by shales and immature clastic sediments (greywackes). Their chondrite normalized REE patterns show a moderate LREE enrichment $(\mathrm{LaN} / \mathrm{YbN}=9.46-15.50)$, flat HREE profiles and negative $\mathrm{Eu}$ anomalies $\left(E \mathrm{Eu} / \mathrm{Eu}^{*}=0.63-0.82\right)$, closely resembling those of PAAS (Post-Archean average Australian Shale) and Early Proterozoic Greywackes. Geochemical data also suggest that the precursor sediments of the Granja paragneisses derived from source areas of felsic to intermediate composition and were deposited in a tectonically active continental margin / continental island arc setting.
\end{abstract}

Keywords: Brasiliano granulite metamorphism; migmatitic paragneisses; provenance

Recibido el 21 de abril de 2014 / Aceptado el 2 de octubre de 2014 / Publicado online el 11 de noviembre de 2014

Citation / Cómo citar este artículo: A.J.F. Silva et al. (2014). Petrographical and geochemical signatures of the Granja paragneisses (Médio Coreaú Domain, NW Ceará, Brasil). Estudios Geológicos 70(2): e014. http://dx.doi.org/10.3989/egeol.41750.326.

Copyright: () 2014 CSIC. This is an open-access article distributed under the terms of the Creative Commons Attribution-Non Commercial (by-nc) Spain 3.0 License. 


\section{RESUMEN}

El Complejo Granulítico de Granja (GGC), expuesto en el Dominio Medio Coreaú (NW del Estado de Ceará, Brasil), está constituido predominantemente por paragneises granatíferos con silimanita en cuyo seno se intercalan cuerpos lenticulares, discontinuos, de granulitas máficas y enderbitas. De acuerdo con los datos geocronológicos publicados, este terreno metamórfico de alto grado representa un segmento de un basamento Paleoproterozoico que fue intensamente retrabajado en el Neoproterozoico, durante la Orogénesis Brasiliense / Panafricana (600 Ma).

Los paragneises de Granja son rocas con una fuerte foliación, caracterizadas por la alternancia de niveles oscuros, ricos en granate-biotita-silimanita, y bandas milimétricas leucocráticas cuarzo-feldespáticas interpretadas como resultado de fusión incipiente. Con el incremento del componente fundido, aumenta el espesor de los leucosomas concordantes y las rocas adquieren un aspecto estromático. A estas estructuras se superpone una foliación milonítica asociada a la última reactivación de la Zona de Cizalla de Granja, un accidente con dirección NE-SW y movimiento dextral que atraviesa la zona estudiada. Las asociaciones minerales y las texturas de reacción indican que después de alcanzar las condiciones de fusión parcial en la facies granulítica, las rocas sufrieron descompresión y enfriamiento.

Con el fin de caracterizar la composición de los protolitos de los paragneises de Granja, se analizaron los elementos mayores y tierras raras de doce muestras de aquellas partes de los paragneises migmatíticos en los que la extracción de fundido parece haber sido nula o muy limitada. En el diagrama de clasificación de Herron (1988), las muestras se sitúan en la transición entre los campos de las grauvacas y pelitas, sugiriendo que en la secuencia pre-metamórfica dominaban sedimentos arcillosos y sedimentos clásticos poco maduros (grauvacas). Los patrones de tierras raras normalizados a condrita muestran un moderado enriquecimiento en las tierras raras ligeras ( $\mathrm{LaN} / \mathrm{YbN}=9.46-15.50)$, perfiles planos en tierras raras pesadas y anomalías negativas de Eu $\left(E u / E^{*}=0.63-0.82\right)$, con pautas muy próximas tanto a las del PAAS (Post-Archean average Australian Shale) como a las del EP GREY (Early Proterozoic Greywackes). Los datos geoquímicos sugieren también que los sedimentos precursores de los paragneises de Granja tuvieron su origen en un área fuente con composición félsica a intermedia y fueron acumulados en un ambiente de margen continental activo / arco insular continental.

Palabras clave: Metamorfismo granulítico Brasiliense; paragneises migmatíticos; procedencia

\section{Introduction}

Granulite-facies metamorphic rocks provide crucial insights into the tectonothermal evolution of ancient orogens and deep crustal processes. Due to complex polyphase metamorphic and deformation overprinting, the chemical and textural characteristics of the original sedimentary and igneous precursors of granulite sequences are no longer preserved. Unravelling their previous geological history is a major goal of petrological investigation that can only be achieved by careful and comprehensive geochemical and isotope studies.

The main objective of this work is to summarize new and available petrographical and geochemical data for the kinzigitic gneisses exposed in the Médio Coreaú Domain in NE Brasil and use whole-rock geochemistry to discriminate their original protolith signatures and identify potential sediment source areas and the tectonic setting prevailing at the time of sedimentation.

\section{Geological Setting}

The Granja region is located in NW Ceará, NE Brasil, at latitudes between $02^{\circ} 47^{\prime} \mathrm{S}-03^{\circ} 22^{\prime} \mathrm{S}$ and longitudes between $40^{\circ} 20^{\prime} \mathrm{W}-41^{\circ} 24^{\prime} \mathrm{W}$ (Figs. 1 and 2).
Geologically, the area is included within the Borborema Province (BP), which represents a segment of the Brasiliano / Pan-African orogenic belt developed by the collision of the Congo-São Francisco and São Luís-West African cratons during the amalgamation of West Gondwana, in the Late Neoproterozoic (ca. $600 \mathrm{Ma}$ ) (Almeida et al., 1981; Cordani et al., 2000). Covering an area of over $400,000 \mathrm{Km}^{2}$, the BP is divided into three main structural blocks: the Northern domain, the Transversal domain and the Southern domain, bounded by a system of sinuous and branched crustal scale shear zones (Caby, 1989).

Based on tectonostratigraphic and geochronological (U-Pb, Sm-Nd) evidence, the Northern block was further subdivided into the following major units, from north to south: the Médio Coreaú, the Ceará Central and the Rio Grande do Norte domains, bordered by the Patos, Senador Pompeu and Transbrasiliano shear zones (Santos et al., 2008; Fig. 1).

As shown in Figures 1 and 2, the study area is situated within the Médio Coreaú Domain (MCD). The oldest rocks exposed in the MCD are Early Paleoproterozoic and span a wide spectrum of lithological types, ranging from orthogneisses with 


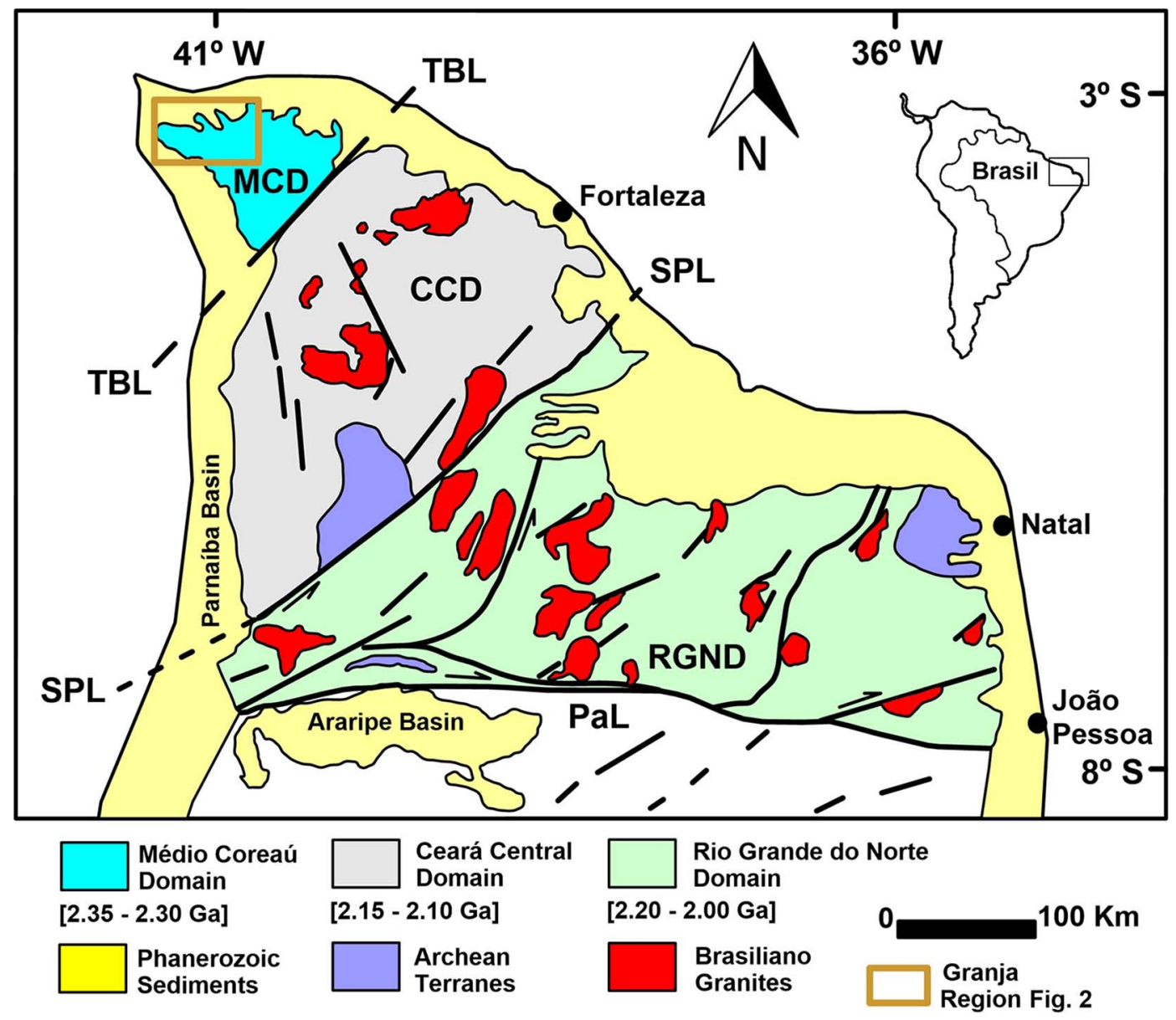

Fig. 1.-Geological map for the northern part of the Borborema Province, showing the location of the Médio Coreaú Domain (modified from Santos et al., 2008). TBL - Transbrasiliano Lineament; SPL; Senador Pompeu Lineament; PaL - Patos Lineament.

tonalite-trondhjemite-granodiorite (TTG) affinities to hornblende gneisses, amphibolites, mafic granulites, enderbites, kinzigites and khondalites (Santos et al., 2009; Amaral et al., 2012). U-Pb zircon ages obtained for the TTG orthogneisses $(2.36-2.29 \mathrm{Ga})$ provide reliable time constraints for the crystallization age of their igneous protoliths, whilst the positive $\varepsilon \mathrm{Nd}_{i}$ values displayed by this rock suite point to a mantle-derived origin in an arc-type geodynamic setting (Fetter et al., 2000; Nogueira Neto, 2000; Santos et al., 2008, 2009; Amaral et al., 2012; Praxedes et al., 2012). According to Fetter et al. (2000), the precursors of both the igneous-derived mafic granulites and enderbites and the granulitic paragneisses (kinzigites and khondalites) have also an Early Paleoproterozoic age.

During the Brasiliano / Pan-African Orogeny, all the MCD basement sequences were extensively affected by high-grade regional metamorphism and migmatization. Estimated peak metamorphic conditions vary between $7-10 \mathrm{kbar}$ and $750-840^{\circ} \mathrm{C}$ for the mafic granulites and granulitic paragneisses and between 5-6 kbar and $600-700^{\circ} \mathrm{C}$ for the TTG orthogneisses (Nogueira Neto, 2000). The age of the Brasiliano migmatitic / granulitic metamorphic event is reasonably well constrained at ca. $600 \mathrm{Ma}$ by U-Pb and Ar-Ar geochronological data (e.g. Monié et al., 1997; Fetter et al., 2000; Santos et al., 2008, 2009).

The MCD high-grade metamorphic complex is partially overlain by supracrustal volcanosedimentary and/or sedimentary successions belonging either to the Late Paleoproterozoic Saquinho sequence or to the Neoproterozoic Martinópole-Ubajara groups (e.g. Santos et al., 2008, 2009; Amaral et al., 2012). Both the infra- and the supracrustal rock suites were 


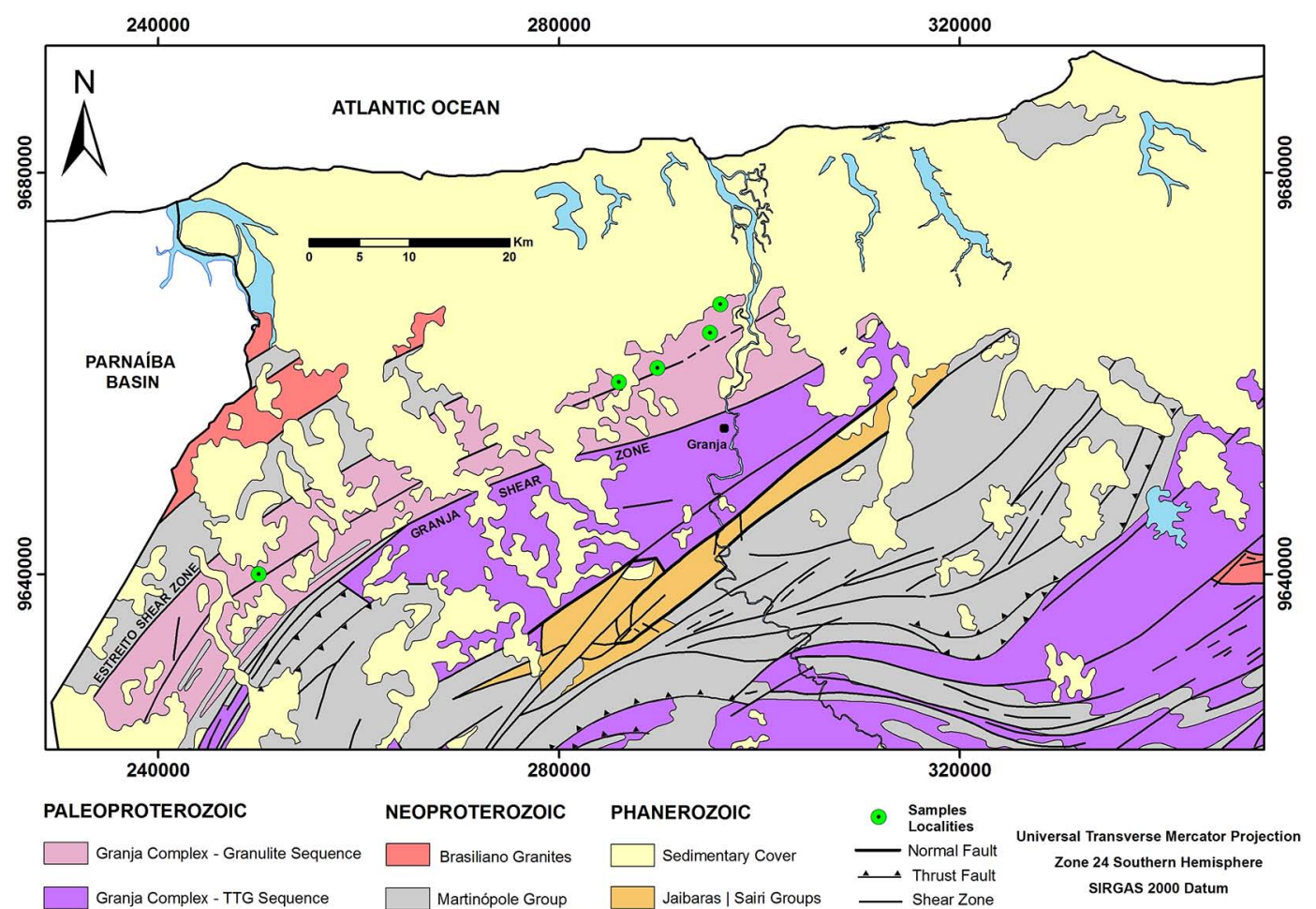

Fig. 2.- Simplified geological map for the Granja region, showing the location of the analysed samples (modified from Cavalcante et al., 2003).

intruded by syn- to post-tectonic Brasiliano granitoids with ages ranging between 590-532 Ma (Santos et al., 2008). Finally, the Early Paleozoic sediments of the Jaibaras/Sairi troughs correspond to early molasse-type deposits post-dating the Brasiliano collage (Santos et al., 2008).

\section{The Granja Granulite Complex}

The Granja Granulite Complex (GGC) constitutes a NE-SW-trending belt occupying the western sector of the MCD (Fig. 2). It contacts with the TTG migmatitic gneisses to the SE through the Granja dextral Shear Zone and with the supracrustal Martinópole sequence to the NW through the Estreito dextral Shear Zone (Fig. 2). The GGC is mainly composed of garnet-sillimanite migmatitic paragneisses enclosing distended lenses of mafic granulites, enderbites and enderbitic gneisses.

At outcrop scale, the high-grade garnet-sillimanite migmatitic paragneisses are well-foliated fine- to medium-grained grey rocks characterized by the alternance of dark garnet-biotite-sillimanite-rich layers and millimeter-thick leucocratic quartz-feldspathic bands, interpreted as indicative of incipient melting (Fig. 3a). For increasing melt fractions, the leucosomes grade into thicker concordant veintype leucosomes producing a conspicuous NE-SW trending stromatic layering, plunging $50-60^{\circ}$ to SE (Fig. 3b). Field evidence reveals that the migmatitic fabrics were developed during the second and third Brasiliano deformation phases $\left(\mathrm{D}_{2}\right.$ and $\left.\mathrm{D}_{3}\right)$.

The metric to decametric bodies of mafic granulites and enderbites enclosed in the migmatitic paragneisses from the GGC consist of dark grey to dark greenish-grey coloured rocks with textures ranging from fine- to medium-grained granoblastic to slightly banded. A weak NE-SW trending $\mathrm{S}_{2+3}$ foliation can also be observed in these lithologies.

The $\mathrm{S}_{2+3}$ tectonic fabrics recorded in both sequences (paragneisses / mafic granulites + enderbites) were heterogeneously folded and overprinted by $\mathrm{D}_{4}$. In the studied area, the last Brasiliano ductile deformation event $\left(\mathrm{D}_{4}\right)$ is related to the reactivation of the dextral Granja Shear Zone (GSZ) and produced a NE-SW striking foliation, steeply dipping towards 

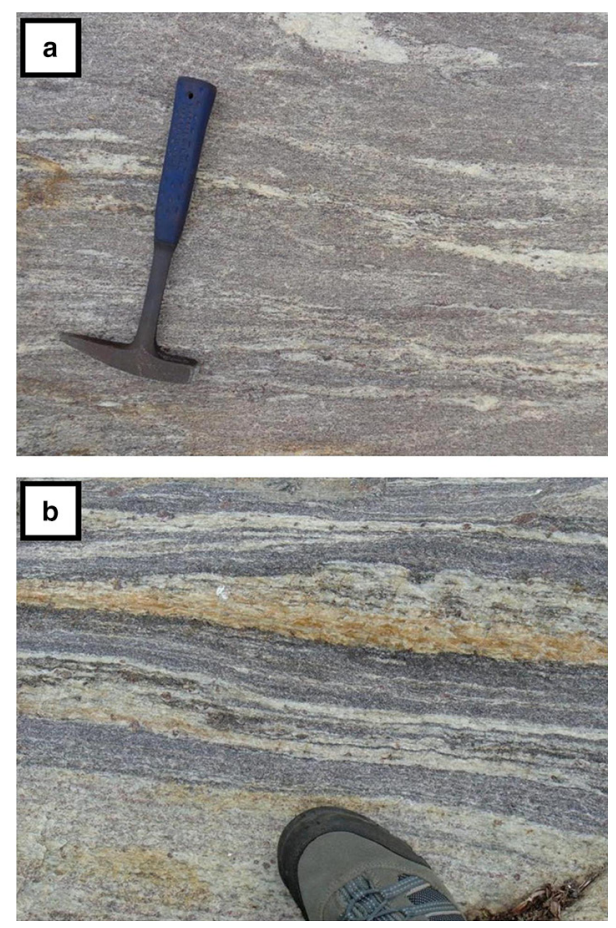

Fig. 3.-Field appearance of the Granja paragneisses: (a) mylonitic fabric in migmatitic paragneiss (b) Coarse garnet-bearing leucosomes in stromatic metatexite.

the SE $\left(>70^{\circ}\right)$. Mineral stretching lineations plunge gently towards northeast or southwest. In high-strain domains, a strong mylonitic / blastomylonitic fabric can be developed and the leucosomes are frequently boudinaged. Asymmetric S/C structures, when present, indicate a dominant dextral sense of movement.

\section{Petrography}

Petrographically, the garnet-sillimanite paragneisses display significant grain size reduction and strong $\mathrm{S}_{4}$ mylonitic fabrics, obscuring their previous metamorphic textures. The high-grade mineral assemblage is dominated by garnet (Grt), sillimanite (Sil), biotite $(\mathrm{Bt})$, quartz $(\mathrm{Qz})$ and plagioclase $(\mathrm{Plg})$ (Figs. 4a-b). K-feldspar (Kfs) and cordierite (Crd) are occasionally present. Accessory minerals include opaques (Opq), apatite (Ap), zircon (Zrn) and rutile (Rt).

In the paragneisses affected by incipient melting, the gneissic fabric is defined by the alternance of millimeter-thick biotite-sillimanite-rich and highly recrystallized quartz-feldspar layers. Garnet is abundant and may constitute large poikiloblasts (up to $2,5 \mathrm{~cm}$ ) wrapped by the granolepidoblastic matrix (Fig. 4c) or smaller, rounded to subhedral, inclusion-free porphyroblasts. Cordierite is anhedral to subhedral and occurs in close spatial association with biotite and sillimanite but can also be found in contact with quartz and feldspars.

As melt contents increase, layer-parallel leucosomes become thicker ( $>5 \mathrm{~cm}$ up to $20 \mathrm{~cm}$ ) and the migmatitic paragneisses grade into stromatic metatexites. The coarser stromatic leucosomes show also fine-grained mylonitic or blastomylonitic fabrics and are predominantly composed of quartz (30-40 vol.\%), plagioclase (20 vol.\%), K-feldspar (10-20 vol.\%), garnet (5 vol.\%) and minor proportions of biotite and fibrolitic sillimanite. Zircon, monazite, apatite and opaques are common accessory phases. Quartz is generally present as finely recrystallized elongate grains with undulose extinction, deformation bands and lobated edges or as ribbonlike aggregates. Plagioclase dominates over alkali feldspar and exhibits wedged and flexured twins (Fig. 4d). K-feldspar is perthitic orthoclase and may occur as small augen mantled by rims of fine grained quartz-feldspar aggregates (Fig. 4e) or as anhedral interstitial crystals in the matrix. Myrmekites are occasionally present. In these leucosomes, the garnet porphyroblasts are generally rounded to subhedral, highly fractured and devoid of inclusions (Fig. 4f). Biotite has a yellow-reddish to reddish-brown pleochroism and is frequently intergrown with fibrolitic sillimanite in very thin biotite-sillimanite selvages wrapping around the garnet neoblasts (Fig. 4f).

Evidence for the earlier $\mathrm{S}_{1}$ fabric is only preserved as a discordant internal foliation $\left(\mathrm{S}_{\mathrm{i}}\right)$ defined by inclusion trails of kyanite (rare), sillimanite, biotite, quartz, plagioclase, ilmenite and rutile within some garnet poikiloblasts. In low-strain domains, the $\mathrm{S}_{2+3}$ gneissic and stromatic banding constitute the main regional fabric observed in these rocks, being strongly transposed by a pervasive anastomosed $\mathrm{S}_{4}$ foliation associated with dextral shearing in highstrain zones. Intense dynamic recrystallization of the leucosomes suggests that much of the $\mathrm{D}_{4}$ deformation was imposed while the migmatites were subsolidus. Prismatic sillimanite and elongated ribbon-like quartz aggregates define a strong sub-horizontal lineation on the $\mathrm{S}_{4}$ foliation planes. 

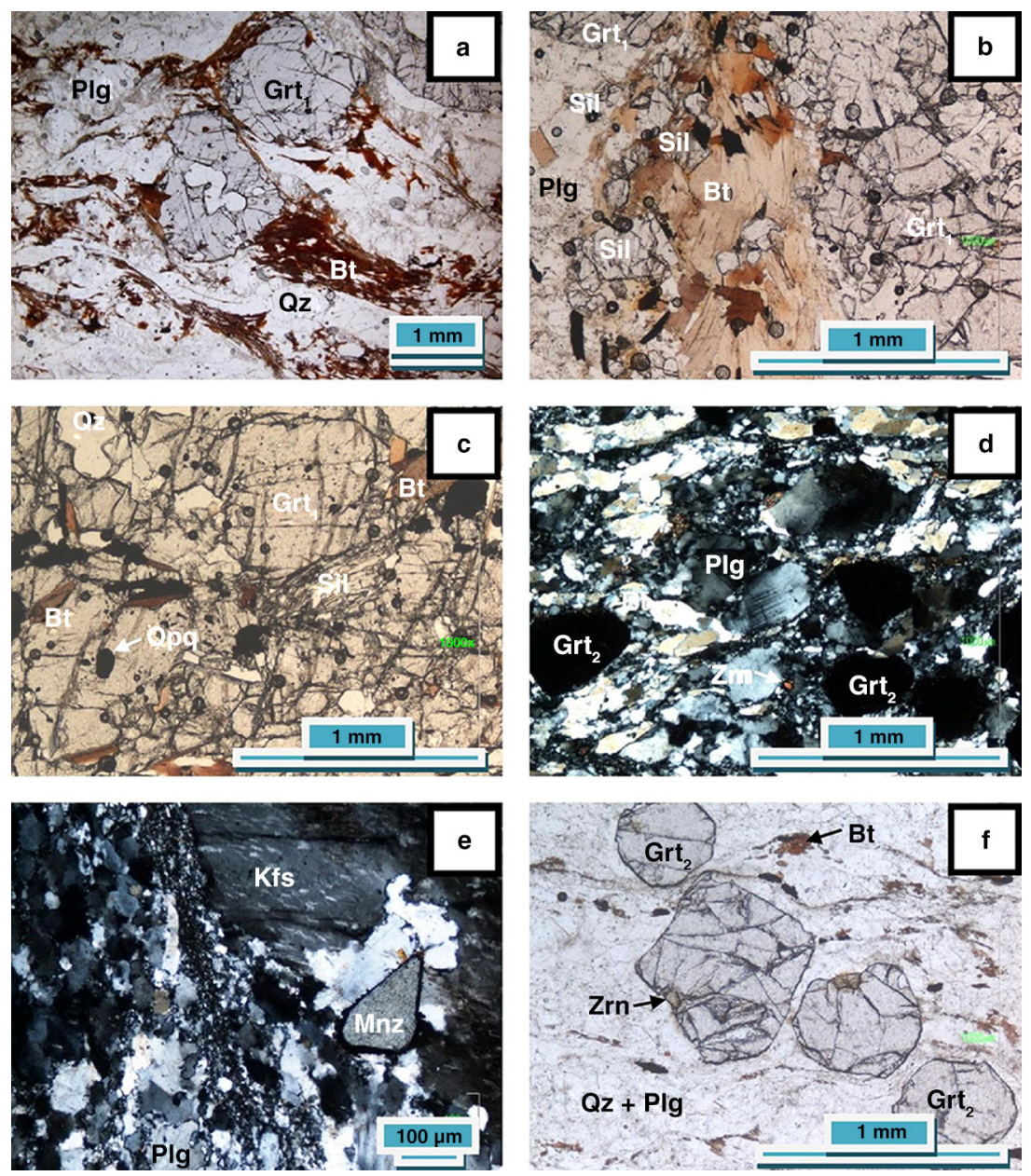

Fig. 4.-(a) High-grade metamorphic mineral assemblage in Granja paragneiss showing a strong $\mathrm{S}_{4}$ mylonitic fabric, plane polarized light; (b) garnet poikiloblasts ( $\mathrm{Grt}_{1}$ ), prismatic silimanite and biotite in paragneiss, plane polarized light; (c) Garnet poikiloblasts (Grt ${ }_{1}$ ) in paragneiss, plane polarized light; (d) Plagioclase with wedged and flexured twins in coarse leucosome, cross polarized light; (e) Augen of microperthitic K-feldspar mantled by finely recrystallized quartz-feldspar aggregates in coarse leucosome, cross polarized light; (f) Inclusion-free subhedral garnet porphyroblasts $\left(\mathrm{Grt}_{2}\right)$ in coarse leucosome, plane polarized light.

\section{Metamorphic evolution}

On the basis of microstructures and relations between mineral phases, it is possible to distinguish four main stages of metamorphism: a prograde metamorphic stage $\left(\mathrm{M}_{1}\right)$, a peak-metamorphic stage $\left(\mathrm{M}_{2}\right)$, a post-peak decompression stage $\left(\mathrm{M}_{3}\right)$ and a retrograde cooling stage $\left(\mathrm{M}_{4}\right)$.

The $\mathrm{M}_{1}$ prograde assemblage is represented by inclusions of kyanite, sillimanite, biotite, quartz, plagioclase, ilmenite and rutile within $\mathrm{M}_{2}$ garnet neoblasts $\left(\mathrm{Grt}_{1}\right)$. The occurrence of very thin leucosomes folded by $\mathrm{D}_{2}$ suggests that partial melting conditions were probably reached during $\mathrm{M}_{1}$ through the muscovite dehydration reaction (Pëto, 1976):

$$
\mathrm{Ms}+\mathrm{Plg}+\mathrm{Qz} \Rightarrow \mathrm{Al}_{2} \mathrm{SiO}_{5}(\mathrm{Sil})+\mathrm{Kfs}+\text { melt }
$$

Following the relict $M_{1}$ metamorphic event, $a M_{2}$ peak-metamorphic paragenesis composed of $\mathrm{Grt}_{1}$ $+\mathrm{Sil}+\mathrm{Bt}+\mathrm{Qz}+\mathrm{Plg}+\mathrm{Kfs}$ was developed involving the fluid-absent incongruent melting reaction of biotite (Le Breton \& Thompson, 1988):

$\mathrm{Bt}+\mathrm{Sil}+\mathrm{Plg}+\mathrm{Qz} \Rightarrow \mathrm{Grt}_{1}+\mathrm{Kfs}+$ melt

The lack of primary muscovite in all the analysed rocks and the presence of millimetre- to centimetrescale quartz-feldspar rich leucosomes parallel to $\mathrm{S}_{2}$ foliation show that the biotite-dehydration melting reaction was crossed during this metamorphic event. 
The $\mathrm{M}_{3}$ metamorphic decompression stage is marked by the first appearance of cordierite, which forms relatively large grains of different shape in the rock matrix. This episode occurred in the sillimanite stability field and was controlled by the reaction (Spear et al., 1999):

$\mathrm{Bt}+\mathrm{Al}_{2} \mathrm{SiO}_{5}(\mathrm{Sil}) \Rightarrow \mathrm{Grt}_{2}+\mathrm{Crd}_{1}+$ melt

$\mathrm{M}_{3}$ led to the production of additional melts and inclusion-free new garnet $\left(\mathrm{Grt}_{2}\right)$, preserved mainly in the leucosomes.

In the last metamorphic stage $\left(\mathrm{M}_{4}\right)$, the earlyformed foliations were reworked by shearing and a strong $\mathrm{S}_{4}$ mylonitic fabric was developed. Reaction textures appear to reflect a cooling history marked by the reversal of reactions 2 and 3 and the crystallization of biotite $\left(\mathrm{Bt}_{2}\right)+$ sillimanite $\left(\mathrm{Sil}_{2}\right)$. The presence of biotite and sillimanite along the rims of garnet neoblasts provides a strong argument in favour of retrogression by garnet consumption. Simultaneously, the melts crystallized and the water released during their solidification contributed to the retrograde reactions.

\section{Analytical methods}

Twelve representative samples of the Granja paragneisses were selected for purposes of geochemical characterization. Sampling strategy involved the collection of specimens that showed no evidence of any significant loss, or gain, of anatectic melts and could therefore provide the closest estimate of the original composition of the protolith. Only the paragneisses containing very thin leucosomes and a relatively homogeneous appearance were selected for chemical analysis. From these, $5-10 \mathrm{~kg}$ of rockmaterial was collected, crushed and split to obtain representative samples of $\sim 250 \mathrm{~g}$. Each sample was finally pulverized in an agate mill. Sample locations are shown in Figure 2.

Sample GR70 was recently collected and analysed for major (ICP-ES) and trace elements (ICP-MS) at ACME Labs (Vancouver, Canada), whilst the geochemical data for the remaining eleven samples were previously obtained by Gama Jr. (1992), Santos (1993) and Nogueira Neto (2000), using X-Ray Fluorescence spectrometry and ICP-MS at GEOSOL
(Belo Horizonte, Brasil). Major and trace element compositions are presented in Tables 1 and 2.

\section{Whole-rock geochemistry}

As previously discussed, the Granja paragneisses experienced granulite facies metamorphism. Their compositions may therefore have been strongly modified by metamorphic overprint and anatexis. However, bulk-rock major and trace element geochemistry provide, in some cases, major constraints on both the nature and the provenance of the putative protoliths for high-grade metamorphic rocks (e.g. Bhatia \& Crook, 1986; Roser \& Korsch 1986, 1988; Otamendi \& Patiño Douce, 2001; Augustsson \& Bahlburg, 2003; Abu El-Enen, 2008, 2011).

The samples from the Granja paragneisses show a relatively wide compositional range with $\mathrm{SiO}_{2}$ between 66.27 and $72.50 \%$ and $\mathrm{Al}_{2} \mathrm{O}_{3}$ between 11.91 and $15.94 \%$. As illustrated in the $\mathrm{P}_{2} \mathrm{O}_{5} / \mathrm{TiO}_{2}$ vs. $\mathrm{MgO} / \mathrm{CaO}$ discrimination diagram proposed by Werner (1987), most of the analysed rocks display low $\mathrm{P}_{2} \mathrm{O}_{5} / \mathrm{TiO}_{2}$ ratios coupled with slightly variable $\mathrm{MgO} / \mathrm{CaO}$ values pointing to a sedimentary origin (Fig. 5). This strongly suggests that the migmatite samples selected for chemical analysis have undergone little or no melt extraction and may therefore have bulk major element compositions similar to those of their original protoliths.

In the $\log \mathrm{Fe}_{2} \mathrm{O}_{3} / \mathrm{K}_{2} \mathrm{O}$ vs. $\log \mathrm{SiO}_{2} / \mathrm{Al}_{2} \mathrm{O}_{3}$ classification diagram of Herron (1988), the investigated migmatitic gneisses plot mainly within the greywacke field or straddle the boundary between the greywacke and shale domains (Fig. 6). Conformable results are obtained using the $\mathrm{Al} / 3-\mathrm{K}$ vs. $\mathrm{Al} / 3-\mathrm{Na}$ (La Roche, 1968) and the $\mathrm{Fe}+\mathrm{Al}+\mathrm{Ti}$ vs. $\mathrm{Ca}+\mathrm{Mg}$ (Moine \& La Roche, 1968) millicationic diagrams (Figs. 7a-b). The low $\mathrm{Ca}$ and $\mathrm{Mg}$ contents observed in these rocks are consistent with the absence of a carbonate component in their precursor sediments.

The empirical discrimination ratio $100 \mathrm{TiO}_{2} / \mathrm{Zr}$ (wt.\%/ppm) based on transition metals (Ti) and HFSE (Zr), which are assumed to have an immobile behaviour during metamorphism, is lower than 0.4 in all the analysed paragneisses and points to a significant input of psammitic material to the original clastic sequence (Garcia et al., 1991; Abu El-Enen, 2011). 
Table 1.-Major element data and sample coordinates for the Granja paragneisses

\begin{tabular}{|c|c|c|c|c|c|c|c|c|c|c|c|c|}
\hline $\begin{array}{l}\text { X - False } \\
\text { Easting }\end{array}$ & 296132 & 295171 & 296062 & 296065 & 289850 & 295085 & 285981 & 250067 & 250067 & 250067 & 295186 & 295205 \\
\hline $\begin{array}{l}\text { Y - False } \\
\text { Northing }\end{array}$ & 9666860 & 9666562 & 9666549 & 9666489 & 9660481 & 9664004 & 9659105 & 9639725 & 9639725 & 9639725 & 9666972 & 9666950 \\
\hline Samples & Jn11 & Jn12 & Jn23-b & Jn23-c & Jn29-b & GR70 & $\mathrm{Jn} 02-\mathrm{C}$ & $209 a$ & $209 b$ & $209 c$ & $\mathrm{~T}-143$ & $\mathrm{~T}-148$ \\
\hline $\mathrm{SiO}_{2}$ & 66.90 & 68.70 & 72.00 & 72.50 & 69.20 & 67.18 & 67.40 & 66.27 & 67.11 & 67.37 & 71.76 & 68.85 \\
\hline $\mathrm{TiO}_{2}$ & 0.59 & 0.60 & 0.61 & 0.52 & 0.66 & 0.54 & 0.73 & 0.74 & 0.59 & 0.44 & 0.74 & 0.76 \\
\hline $\mathrm{Al}_{2} \mathrm{O}_{3}$ & 15.60 & 15.50 & 14.10 & 13.90 & 14.60 & 15.94 & 15.20 & 14.04 & 11.91 & 12.75 & 14.36 & 13.70 \\
\hline $\mathrm{Fe}_{2} \mathrm{O}_{3}(\mathrm{~T})$ & 6.23 & 5.66 & 5.00 & 4.68 & 6.17 & 6.12 & 7.46 & 5.76 & 8.36 & 8.58 & 5.09 & 6.80 \\
\hline $\mathrm{MnO}$ & 0.12 & 0.11 & 0.01 & 0.11 & 0.11 & 0.10 & 0.09 & 0.09 & 0.07 & 0.08 & 0.06 & 0.05 \\
\hline $\mathrm{MgO}$ & 2.10 & 1.60 & 1.40 & 1.30 & 2.10 & 1.80 & 2.10 & 2.69 & 1.54 & 1.35 & 0.71 & 1.46 \\
\hline $\mathrm{CaO}$ & 1.80 & 0.96 & 1.60 & 2.00 & 2.10 & 2.43 & 1.70 & 2.29 & 1.71 & 1.71 & 2.09 & 1.90 \\
\hline $\mathrm{Na}_{2} \mathrm{O}$ & 2.60 & 1.60 & 2.20 & 2.70 & 2.30 & 2.87 & 1.90 & 2.75 & 2.50 & 2.23 & 2.87 & 2.48 \\
\hline $\mathrm{K}_{2} \mathrm{O}$ & 3.00 & 3.90 & 1.90 & 1.30 & 1.70 & 2.84 & 2.10 & 2.81 & 3.09 & 2.99 & 1.64 & 1.94 \\
\hline $\mathrm{P}_{2} \mathrm{O}_{5}$ & 0.08 & 0.08 & 0.07 & 0.07 & 0.05 & 0.07 & 0.12 & 0.16 & 0.08 & 0.08 & 0.07 & 0.07 \\
\hline LOI & 0.01 & 0.38 & 0.13 & 0.07 & 0.07 & -0.10 & 0.01 & 1.75 & 2.11 & 1.47 & 0.25 & 0.33 \\
\hline Total & 99.03 & 99.09 & 99.01 & 99.15 & 99.06 & 99.79 & 98.81 & 99.35 & 99.07 & 99.05 & 99.64 & 98.34 \\
\hline
\end{tabular}

Samples T-143 and T-148 are from Gama Jr. (1992); samples 209a-b-c are from Santos (1993); the other six samples (Jn11, 12, 23b-c, 29b, 02c) are from Nogueira Neto (2000).

Table 2.-Trace element data for the Granja paragneisses. PAAS and EP GREY compositions are given in the last two columns

\begin{tabular}{|c|c|c|c|c|c|c|c|c|}
\hline Sample & Jn11 & Jn12 & Jn23-b & Jn23-C & Jn29-b & GR70 & PAAS $^{*}$ & EP GREY \\
\hline Th & 13.00 & 13.00 & 11.00 & 13.00 & 17.00 & 9.90 & 14.60 & 8.00 \\
\hline $\mathrm{Sc}$ & 14.00 & 15.00 & 8.00 & 10.00 & 10.00 & 13.00 & 16.00 & 15.00 \\
\hline $\mathrm{Zr}$ & 216.00 & 197.00 & 300.00 & 227.00 & 257.00 & 160.90 & 210.00 & 156.00 \\
\hline La & 37.40 & 42.94 & 41.35 & 39.88 & 41.01 & 32.50 & 38.00 & 32.00 \\
\hline $\mathrm{Ce}$ & 81.21 & 94.81 & 88.72 & 84.63 & 83.07 & 64.00 & 80.00 & 68.00 \\
\hline $\operatorname{Pr}$ & - & - & - & - & - & 6.67 & 8.90 & - \\
\hline $\mathrm{Nd}$ & 30.14 & 35.64 & 33.65 & 32.55 & 30.21 & 23.60 & 32.00 & 29.00 \\
\hline $\mathrm{Sm}$ & 5.20 & 6.30 & 6.09 & 5.89 & 5.46 & 4.52 & 5.60 & 5.60 \\
\hline Eu & 0.98 & 1.22 & 1.26 & 1.24 & 1.15 & 1.16 & 1.10 & 1.20 \\
\hline Gd & 4.08 & 4.60 & 4.34 & 4.44 & 4.26 & 3.94 & 4.70 & 4.54 \\
\hline $\mathrm{Tb}$ & - & - & - & - & - & 0.70 & 0.77 & 0.66 \\
\hline Dy & 4.33 & 4.40 & 4.32 & 4.08 & 4.07 & 3.93 & 4.40 & - \\
\hline Ho & 0.90 & 0.90 & 0.90 & 0.88 & 0.84 & 0.82 & 1.00 & - \\
\hline $\mathrm{Er}$ & 2.56 & 2.50 & 2.56 & 2.66 & 2.42 & 2.30 & 2.90 & - \\
\hline $\mathrm{Tm}$ & - & - & - & - & - & 0.36 & 0.40 & - \\
\hline $\mathrm{Yb}$ & 2.06 & 2.18 & 2.08 & 2.22 & 1.79 & 2.32 & 2.80 & 1.80 \\
\hline Lu & 0.31 & 0.33 & 0.32 & 0.35 & 0.28 & 0.34 & 0.43 & 0.29 \\
\hline$\sum \mathrm{REE}$ & 169.15 & 195.82 & 185.59 & 178.81 & 174.56 & 147.16 & 183.00 & 143.09 \\
\hline $\mathrm{Eu} / \mathrm{Eu}^{*}$ & 0.63 & 0.66 & 0.72 & 0.71 & 0.70 & 0.82 & 0.64 & 0.71 \\
\hline $\mathrm{La}_{\mathrm{N}} / \mathrm{Yb}_{\mathrm{N}}$ & 12.27 & 13.28 & 13.40 & 12.11 & 15.50 & 9.46 & 9.16 & 12.00 \\
\hline $\mathrm{Gd}_{\mathrm{N}} / \mathrm{Yb}_{\mathrm{N}}$ & 1.60 & 1.70 & 1.68 & 1.61 & 1.93 & 1.37 & 1.36 & 2.04 \\
\hline
\end{tabular}

"PAAS - Post-Archean average Australian Shale (Nance \& Taylor, 1976); EP GREY - Average Chemical Composition of Early Proterozoic Greywackes (Condie, 1993). 


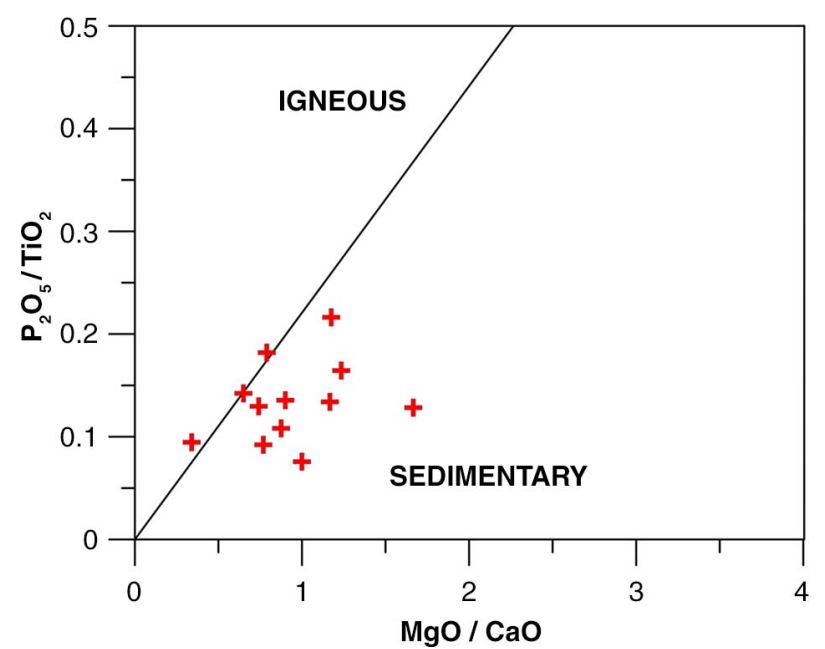

Fig. 5. $-\mathrm{P}_{2} \mathrm{O}_{5} / \mathrm{TiO}_{2}$ versus $\mathrm{MgO} / \mathrm{CaO}$ discrimination diagram (Werner, 1987) for the analysed Granja paragneisses (red symbols).

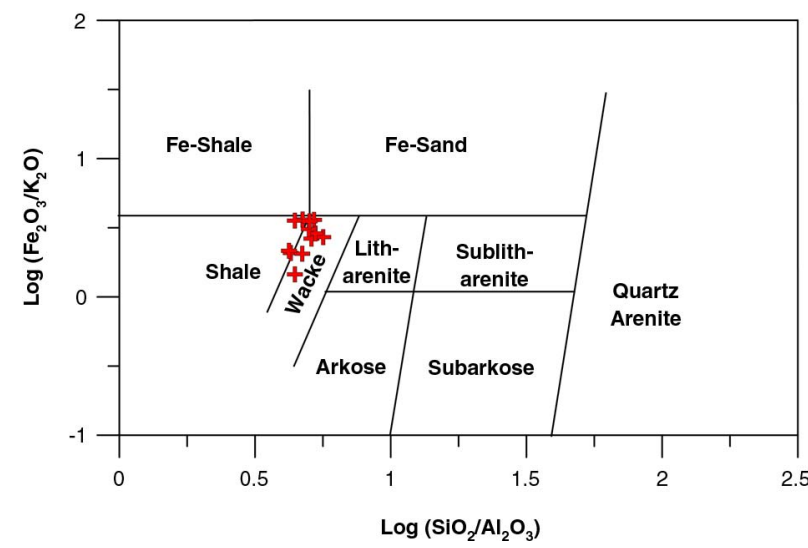

Fig. 6.- - $\mathrm{Log}\left(\mathrm{SiO}_{2} / \mathrm{Al}_{2} \mathrm{O}_{3}\right)$ versus log $\left(\mathrm{Fe}_{2} \mathrm{O}_{3} / \mathrm{K}_{2} \mathrm{O}\right)$ classification diagram of Herron (1988) showing the location of the studied samples (red symbols).

Six of the paragneiss samples have high $\mathrm{K}_{2} \mathrm{O}$ / $\mathrm{Na}_{2} \mathrm{O}$ ratios $(>1)$, whilst the other six display $\mathrm{K}_{2}^{2} \mathrm{O} /$ $\mathrm{Na}_{2} \mathrm{O}$ values lower than 1 , suggesting some diversity of protolith rock types (pelitic to semipelitic). In the A-CN-K ternary plot of Nesbitt \& Young (1984), the samples define a trend between siltclay and clay sediments consistent with a mixed greywacke-shale composition (Fig. 8).

Calculation of the chemical index of alteration (CIA; Nesbitt \& Young 1982) gives CIA values of 53 to 65 indicative of low to moderate degrees of chemical weathering for the sediment parent rocks,

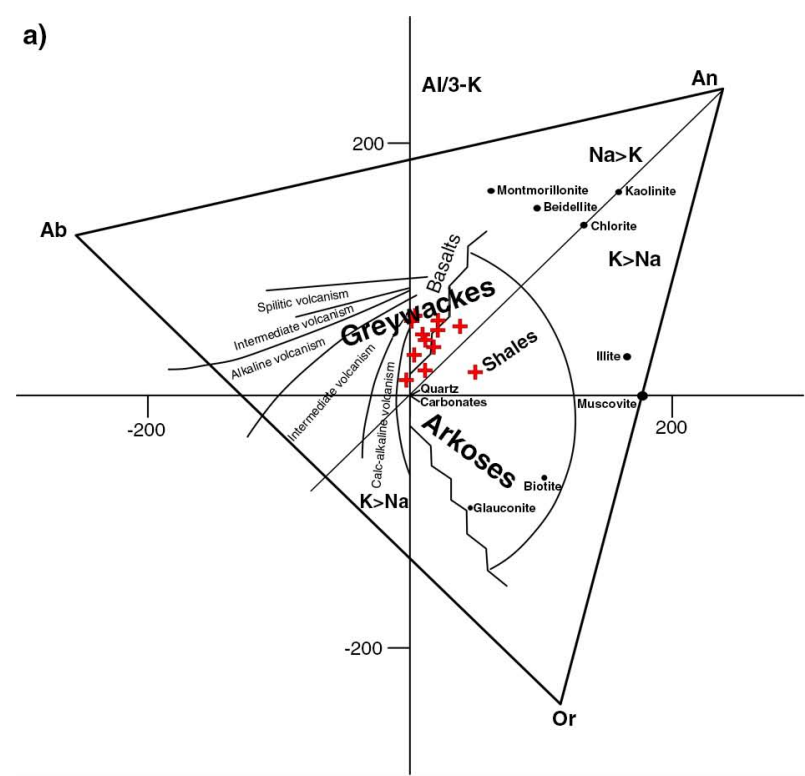

b)

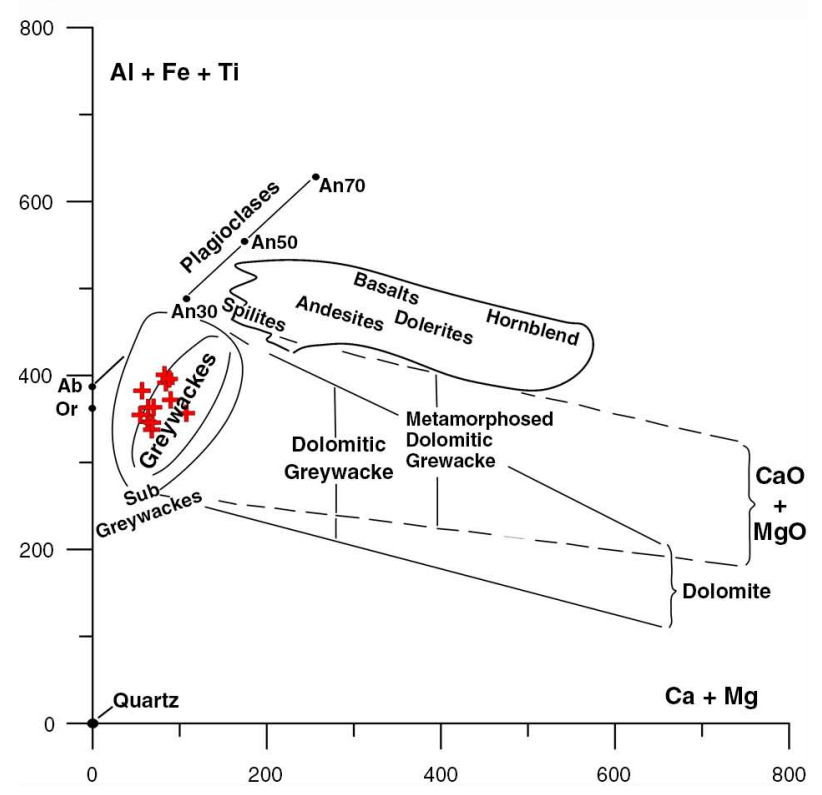

Fig. 7.-(a) Al/3-K versus Al/3-Na millicationic diagram (La Roche, 1968) and (b) Fe $+\mathrm{Al}+\mathrm{Ti}$ versus $\mathrm{Ca}+\mathrm{Mg}$ millicationic diagram (Moine \& La Roche 1968) for the analysed paragneisses (red symbols).

supporting a provenance from igneous felsic to intermediate crustal sources.

Figure 9 illustrates the REE chondrite normalized patterns for six representative samples of the paragneiss suite. Overall, these patterns are characterized by: (a) moderate LREE / HREE fractionation $\left(\mathrm{La}_{\mathrm{N}} / \mathrm{Yb}_{\mathrm{N}}=9.46-15.50\right)$, (b) flat HREE 


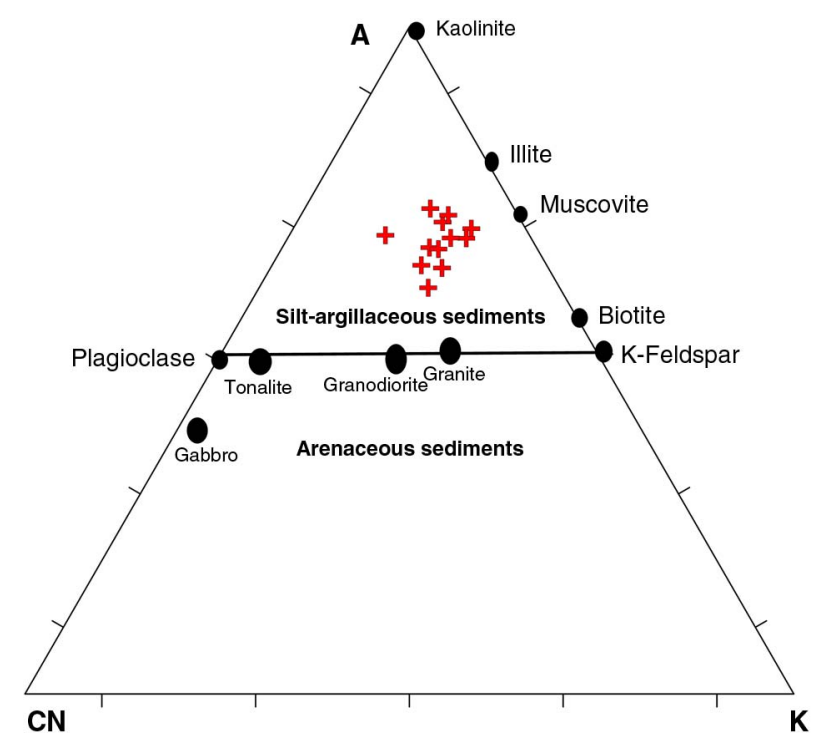

Fig. 8.-A-CN-K ternary plot of Nesbitt \& Young (1984) showing the location of the analysed samples (red symbols). $A=$ mol. $\mathrm{Al}_{2} \mathrm{O}_{3} ; \mathrm{CN}=$ mol. $\mathrm{CaO}{ }^{*}+$ mol. $\mathrm{Na}_{2} \mathrm{O} ; \mathrm{K}=$ mol. $\mathrm{K}_{2} \mathrm{O} . \mathrm{CaO}^{*}=$ mol. CaO-3.33 mol. $\mathrm{P}_{2} \mathrm{O}_{5}$.

profiles $\left(\mathrm{Gd}_{\mathrm{N}} / \mathrm{Yb}_{\mathrm{N}}=1.37-1.93\right)$ and (c) negative $\mathrm{Eu}$ anomalies of small amplitude $\left(\mathrm{Eu} / \mathrm{Eu}^{*}=0.63-0.82\right)$. Their close similarities to Post-Archean average Australian Shale (PAAS, Nance \& Taylor, 1976) and Early Proterozoic Greywackes (EP GREY,

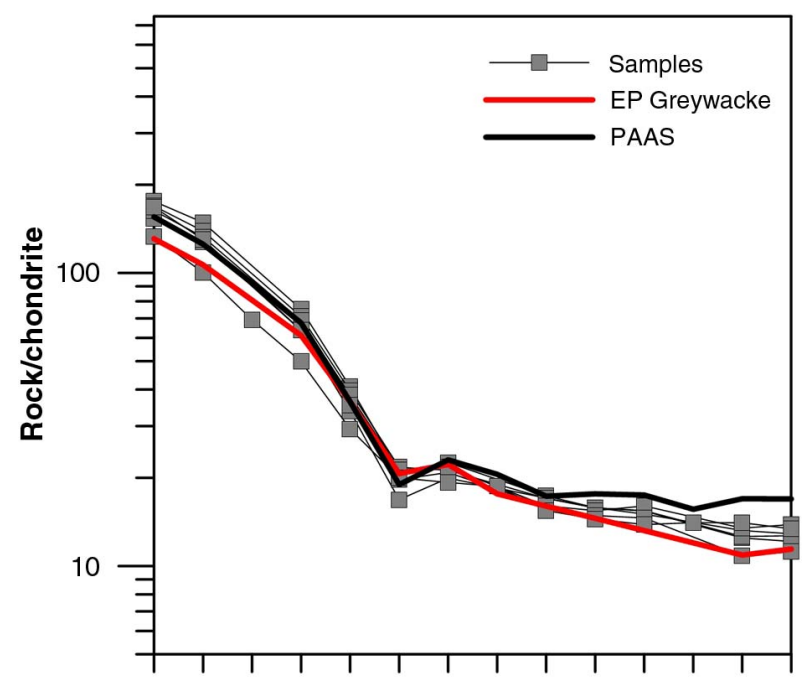

La Ce Pr Nd Sm Eu Gd Tb Dy Ho Er Tm Yb Lu

Fig. 9.-Chondrite normalized REE patterns for the Granja paragneisses (grey squares). Normalization constants from Evensen et al. (1978). Black line represents Post-Archean average Australian Shale (PAAS) and red line Early Proterozoic average Greywacke (EP GREY).
Condie, 1993) provide additional evidence for a pelitic to semipelitic derivation and reinforce the hypothesis that melt loss from these rocks has been negligible. The $\mathrm{Eu} / \mathrm{Eu}^{*}$ and $\mathrm{Gd}_{\mathrm{N}} / \mathrm{Yb}_{\mathrm{N}}$ ratios are also within the range of values $\left(\mathrm{Eu} / \mathrm{Eu}^{*}<0.85\right.$; $\left.\mathrm{Gd}_{\mathrm{N}} / \mathrm{Yb}_{\mathrm{N}}<2.0\right)$ found in Post-Archean metasediments by McLennan \& Taylor (1991) and McLennan et al. (1995) (Fig. 10).

\section{Provenance and tectonic setting}

Several attempts have been made to use major and trace elements as provenance indicators. In the F1-F2 diagram of Roser \& Korsch (1988), the analysed samples plot within the fields of primary felsic or intermediate source rocks pointing to a major contribution of this type of igneous materials for the genesis of their precursor sediments (Fig. 11). Their Th/Sc and $\mathrm{Zr} / \mathrm{Sc}$ ratios are similar to the upper continental crust (McLennan et al., 1993) confirming their provenance from a felsic to intermediate source area (Fig. 12).

According to the $\mathrm{K}_{2} \mathrm{O} / \mathrm{Na}_{2} \mathrm{O}$ vs. $\mathrm{SiO}_{2}$ diagram of Roser \& Korsch (1986), sediment deposition would have occurred at an active continental margin (Fig. 13). As shown in the ternary diagrams of Bhatia \& Crook (1986), a continental island arc setting is

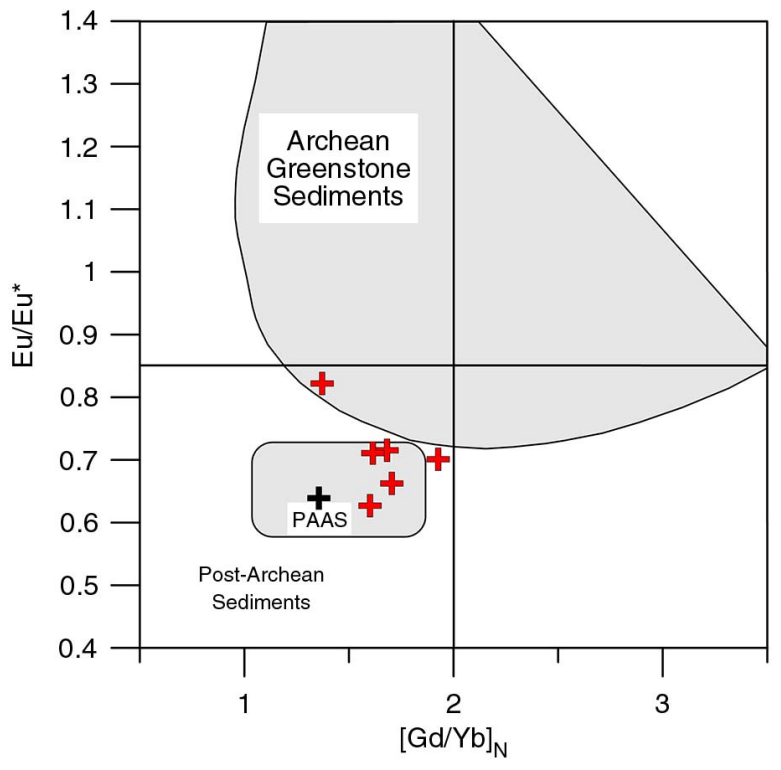

Fig. 10.-Eu/Eu* versus GdN/YbN diagram (McLennan \& Taylor, 1991) for the analysed samples. Shadowed fields correspond to Post-Archean Sediments and Archean Greenstone Sediments (McLennan et al., 1995). 


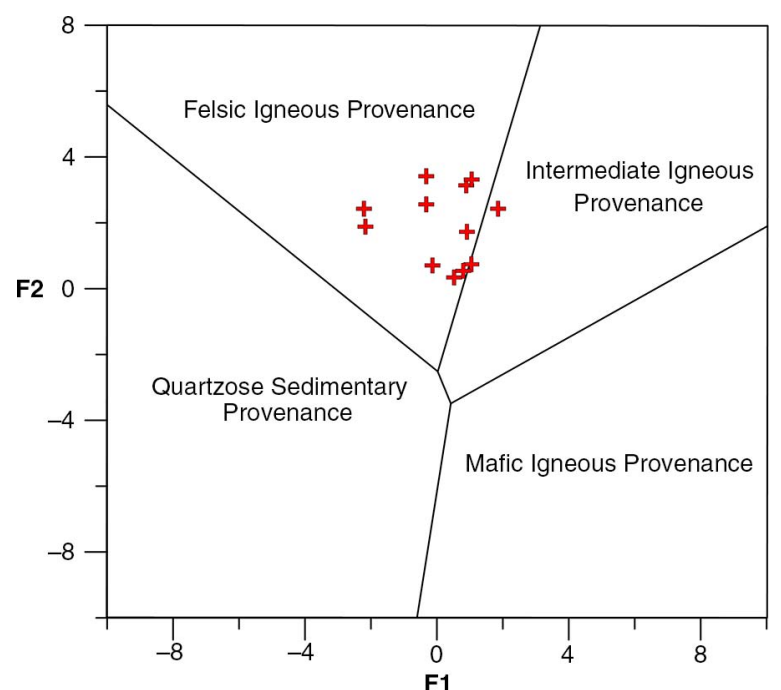

Fig. 11.-Classification of the analysed samples (red symbols) according to the provenance discrimination diagram proposed by Roser \& Korsch (1988). $\mathrm{F} 1=\left(-1.773 \mathrm{TiO}_{2}+0.607 \mathrm{Al}_{2} \mathrm{O}_{3}+0.76\right.$ $\left.\mathrm{Fe}_{2} \mathrm{O}_{3} \mathrm{t}-1.5 \mathrm{MgO}+0.616 \mathrm{CaO}+0.509 \mathrm{Na}_{2} \mathrm{O}-1.224 \mathrm{~K}_{2} \mathrm{O}\right)-9.09$; $\mathrm{F} 2=\left(0.445 \mathrm{TiO}_{2}+0.07 \mathrm{Al}_{2} \mathrm{O}_{3}-0.25 \mathrm{Fe}_{2} \mathrm{O}_{3} \mathrm{t}-1.142 \mathrm{MgO}+0.438\right.$ $\left.\mathrm{CaO}+1.475 \mathrm{Na}_{2} \mathrm{O}+1.426 \mathrm{~K}_{2} \mathrm{O}\right)-6.861$.

indicated by the highly incompatible trace elements (La, Sc, Th, Zr) for the investigated paragneisses (Figs. 14a-b).

Finally, regional constraints suggest that the sedimentary protoliths of the Granja granulitic paragneisses could have resulted from erosion of intermediate to felsic igneous rocks similar to the TTG orthogneisses exposed in adjacent areas of the MCD (Fig. 2). This is

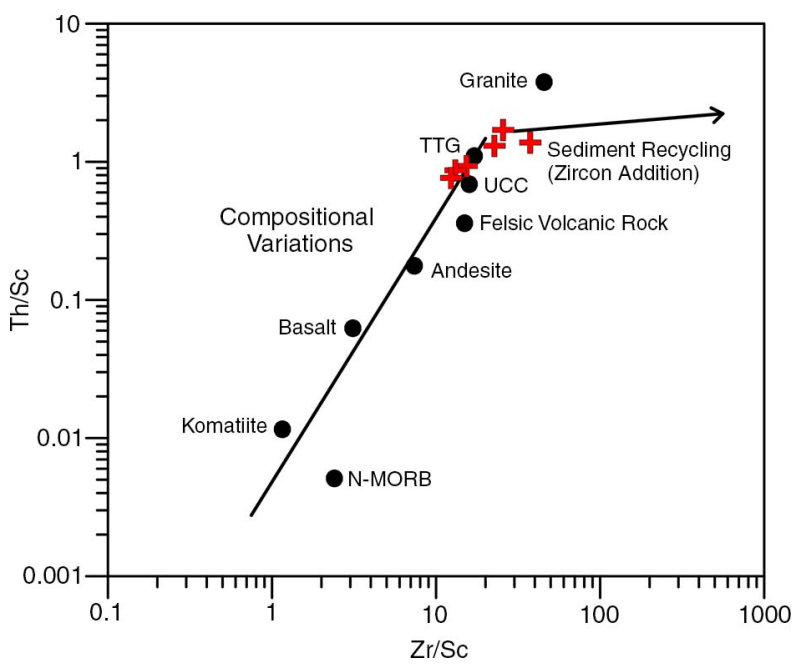

Fig. 12.-Th/Sc versus Zr/Sc diagram (McLennan et al., 1993) for the studied samples (red symbols).

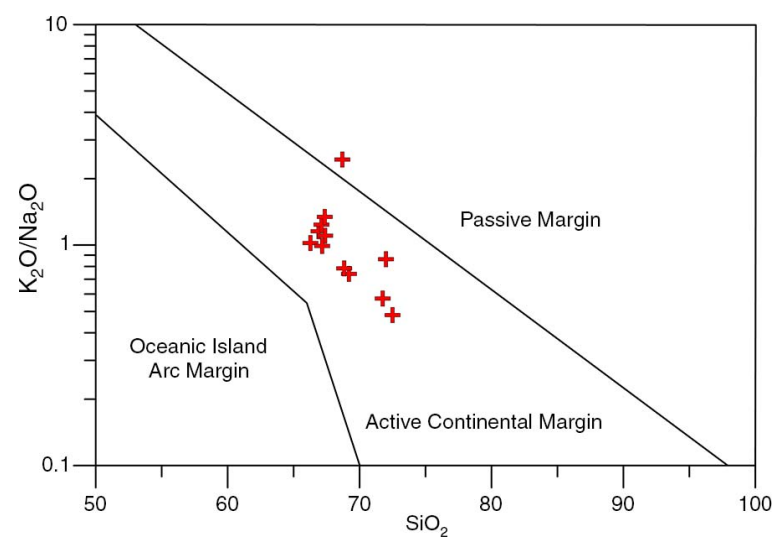

Fig. 13. $-\mathrm{K}_{2} \mathrm{O} / \mathrm{Na}_{2} \mathrm{O}$ versus $\mathrm{SiO}_{2}$ tectonic setting discrimination diagram of Roser \& Korsch (1986) showing the location of the studied samples (red symbols).

further supported by the Early Proterozoic U-Pb ages obtained in detrital zircons from the paragneisses and the island arc tectonic setting inferred for the TTG sequence (Fetter et al., 2000).

\section{Conclusions}

Based on the preliminary petrographical and geochemical data presented in this study, it is possible to draw the following conclusions:

The garnet-sillimanite migmatitic paragneisses exposed in the MCD experienced intense deformation and granulite facies metamorphism during the Brasiliano Orogeny. Microstructures and mineral assemblages in the Granja paragneisses reveal a metamorphic history involving four main stages: a prograde metamorphic stage $\left(\mathrm{M}_{1}\right)$, a peak-metamorphic stage $\left(\mathrm{M}_{2}\right)$, a post-peak decompression stage $\left(\mathrm{M}_{3}\right)$ and a retrograde cooling stage $\left(\mathrm{M}_{4}\right)$.

Partial melting conditions appear to have been reached during $\mathrm{M}_{1}$, continued during the metamorphic peak $\left(\mathrm{M}_{2}\right)$ and persisted during most of the post-peak decompression stage $\left(\mathrm{M}_{3}\right)$. The retrograde cooling path $\left(M_{4}\right)$ is coeval with $D_{4}$ shearing and was accompanied by intense dynamic recrystallization of the leucosomes suggesting that melt crystallization was completed before the end of the $\mathrm{D}_{4}$ tectonic event.

Some of the migmatitic paragneisses from the Granja Granulite Complex appear to have undergone little or no melt extraction and provide the closest estimate for the composition of the original 

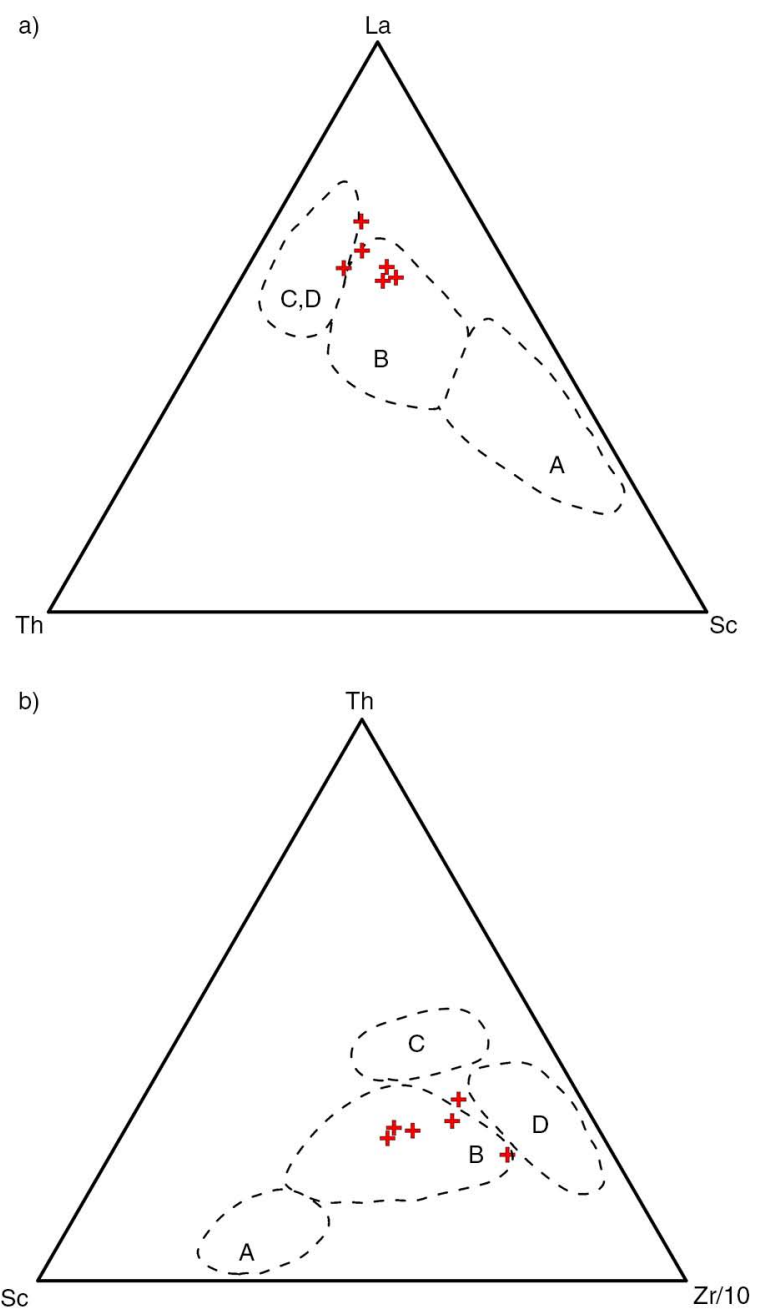

Fig. 14.-Tectonic setting ternary discrimination diagrams (Bhatia \& Crook, 1986) for the analysed samples (red symbols). (a) La-Th-Sc, (b) Th-Sc-Zr/10. Dashed fields correspond to (A) Oceanic Island Arc, (B) Continental Island Arc, (C) Active Continental Margin and (D) Passive Margin.

protoliths. Whole-rock geochemical data for these rocks suggest that the precursor sediments had mixed greywacke-shale compositions and could have resulted from erosion of intermediate to felsic igneous rocks similar to the TTG orthogneisses. Sediment deposition would have occurred at an active continental marginal / continental island arc setting.

Given the evidence for the presence of melt in the samples analysed, the results obtained must be interpreted with caution and any inferences on the provenance of the Granja paragneisses require further support from isotopic and detrital zircon studies.

\section{ACKNOWLEDGMENTS}

This work was supported by the project Metamorphic Evolution of the Granja Complex \& Metalogenetic Potential of the Central Ceará Pegmatites (SPU N 11294909-6, FUNCAP, Brasil) and the GeoBioTec Research Unit (PEst-OE/CTE/UI4035/2014). The authors also thank the Department of Geology of the Federal University of Ceará (UFC), the Institute of Geosciences and Exact Sciences of the São Paulo State University (UNESP) and the Department of Geosciences of the University of Aveiro (UA). A.J.F. Silva benefits from a $\mathrm{PhD}$ grant (SFRH/BD/85292/2012) sponsored by FCT (Science and Technology Foundation, Portugal). Valuable comments on the original manuscript by C. Villaseca and an anonymous reviewer are greatly appreciated.

\section{References}

Abu El-Enen, M.M. (2008). Geochemistry and metamorphism of the Pan-African back-arc Malhaq volcano-sedimentary Neoproterozoic association, W. Kid area, SE Sinai, Egypt. Journal of African Earth Sciences, 51: 189-206. http://dx.doi.org/10.1016/j. jafrearsci.2008.01.004.

Abu El-Enen, M.M. (2011). Geochemistry, provenance, and metamorphic evolution of Gabal Samra Neoproterozoic metapelites, Sinai, Egypt. Journal of African Earth Sciences, 59: 269-282. http://dx.doi. org/10.1016/j.jafrearsci.2010.11.002.

Almeida, F.F.M.; Hasui, Y.; Brito Neves, B.B. \& Fuck, R.A. (1981). Brazilian structural provinces: an introduction. Earth Sciences Reviews, 17: 1-29. http:// dx.doi.org/10.1016/0012-8252(81)90003-9.

Amaral, W.S.; Santos, T.J.S.; Wernick, E.; Nogueira Neto, J.A.; Dantas, E.L. \& Matteini, M. (2012). Highpressure granulites from Cariré, Borborema Province, NE Brazil: Tectonic setting, metamorphic conditions and $\mathrm{U}-\mathrm{Pb}$, Lu-Hf and $\mathrm{Sm}-\mathrm{Nd}$ geochronology. Gondwana Research, 22: 892-909. http://dx.doi. org/10.1016/j.gr.2012.02.011.

Augustsson, C. \& Bahlburg, H. (2003). Active or passive continental margin? Geochemical and Nd isotope constraints of metasediments in the backstop of a pre-Andean accretionary wedge in southernmost Chile $\left(46^{\circ} 30^{\prime}-48^{\circ} 30^{\prime} \mathrm{S}\right)$. In: Tracing Tectonic Deformation Using the Sedimentary Record (McCann, T. \& Saintot, A.; Eds.), Geological Society, London, Special Publications, 208: 253-268. http://dx.doi. org/10.1144/GSL.SP.2003.208.01.12.

Bhatia, M.R. \& Crook, K.A.W. (1986). Trace element characteristics of graywackes and tectonic setting discrimination of sedimentary basins. Contributions to Mineralogy and Petrology, 92: 181-193. http:// dx.doi.org/10.1007/BF00375292.

Caby, R. (1989). Precambrian terranes of Benin-Nigeria and northeast Brazil and the Late Proterozoic south Atlantic fit. Geological Society of America Special Paper, 230: 145-158. 
Cavalcante, J.C.; Vasconcelos, A.M.; Medeiros, M.F.; Paiva, L.P.; Gomes, F.E.M.; Cavalcante, S.N.; Cavalcante, J.E.; Melo, A.C.R.; Duarte Neto, V.C. \& Benevides, H.C. (2003). Mapa Geológico do Estado do Ceará - 1:500.000, Fortaleza, Companhia de Pesquisa de Recursos Minerais (CPRM) - Geological Survey of Brazil.

Condie, K.C. (1993). Chemical composition and evolution of the upper continental crust: Contrasting results from surface samples and shales. Chemical Geology, 104: 1-37. http://dx.doi.org/10.1016/0009-2541(93)90140-E.

Cordani, U.G.; Sato, K.; Teixeira, W.; Tassinari, C.C.G. \& Basei, M.A.S. (2000). Crustal Evolution of the South American Platform. In: Tectonic Evolution of South America (Cordani, U. G.; Milani, E. J.; Thomaz Filho, A. \& Campos, D. A.; Eds.), Sociedade Brasileira de Geologia, Rio de Janeiro, 19-40.

Evensen, N.M.; Hamilton, P.J. \& O’Nions, R.K. (1978). Rare-earth abundances in chondritic meteorites. Geochimica et Cosmochimica Acta, 42: 1199-1212. http://dx.doi.org/10.1016/0016-7037(78)90114-X.

Fetter, A.H.; Van Schmus, W.R.; Santos, T.J.S.; Nogueira Neto, J.A. \& Arthaud, M.H. (2000). U/Pb and Sm/Nd Geochronological Constraints on the Crustal Evolution and Basement Architecture of Ceará State, NW Borborema Province, NE Brazil: Implications for the Existence of the Paleoproterozoic Supercontinent "Atlantica". Revista Brasileira de Geociências, 30: 102-106.

Gama Jr, T. (1992). Geologia do setor nordeste da zona de cisalhamento de Granja - noroeste do Ceará. PhD Thesis. Universidade Federal do Pará, Belém, Brasil, $174 \mathrm{pp}$.

Garcia, D.; Coelho, J.; Perrin, M. (1991). Fractionation between $\mathrm{TiO} 2$ and $\mathrm{Zr}$ as a measure of sorting within shale and sandstone series (northern Portugal). European Journal of Mineralogy, 3: 401-414. http:// dx.doi.org/10.1127/ejm/3/2/0401 .

Herron, M.M. (1988). Geochemical classification of terrigenous sands and shales from core or log data. Journal of Sedimentary Petrology, 58: 820-829. http://dx.doi.org/10.1306/212F8E77-2B24-11D78648000102C1865D.

La Roche, H. (1968). Comportement géochimique différentiel de $\mathrm{Na}, \mathrm{K}$ et $\mathrm{Al}$ dans les formations volcaniques et sédimentaires: un guide pour l'étude des formations métamorphiques et plutoniques. Comptes Rendus de l'Académie des Sciences de Paris, 267: 39-42.

Le Breton, N. \& Thompson, A.B. (1988). Fluid-absent (dehydration) melting of biotite in metapelites in the early stages of crustal anatexis. Contributions to Mineralogy and Petrology, 99: 226-237. http:// dx.doi.org/10.1007/BF00371463.

McLennan, S.M. \& Taylor, S.R. (1991). Sedimentary Rocks and Crustal Evolution: Tectonic Setting and Secular Trends. Journal of Geology, 99: 1-21. http:// dx.doi.org/10.1086/629470.
McLennan, S.M.; Hemming, S.; McDaniel, D.K. \& Hanson, G.N. (1993). Geochemical approaches to sedimentation, provenance and tectonics. In: Processes Controlling the Composition of Clastic Sediments (Johnsson, M.J. \& Basu, A.; Eds.), Geological Society of America Special Papers, 285: 21-40. http://dx.doi.org/10.1130/SPE284-p21.

McLennan, S.M.; Hemming, S.R.; Taylor, S.R. \& Eriksson, K.A. (1995). Early Proterozoic crustal evolution: Geochemical and $\mathrm{Nd}-\mathrm{Pb}$ isotopic evidence from metasedimentary rocks, southwestern North America. Geochimica et Cosmochimica Acta, 59: 1153-1177. http://dx.doi.org/10.1016/0016-7037(95) 00032-U.

Moine, B. \& La Roche, H. (1968). Nouvelle approche du problème d'origine des amphibolites à partir de leur composition chimique. Comptes Rendus de l'Académie des Sciences de Paris, 267: 2084-2087.

Monié, P.; Caby, R. \& Arthaud, M.H. (1997). Timing of the Neoproterozoic Brasiliano Orogeny in northeast Brazil: 40Ar/39Ar ages and petrostructural data from Ceará. Precambrian Research, 81: 241-264. http:// dx.doi.org/10.1016/S0301-9268(96)00037-X.

Nance, W.B. \& Taylor, S.R. (1976). Rare-Earth Element Patterns and Crustal Evolution, Australian Post-Archean Sedimentary-Rocks. Geochimica et Cosmochimica Acta, 40: 1539-1551. http://dx.doi. org/10.1016/0016-7037(76)90093-4.

Nesbitt, H.W. \& Young, G.M. (1982). Early Proterozoic climates and plate motions inferred from major element chemistry of lutites. Nature, 299: 715-717. http://dx.doi.org/10.1038/299715a0.

Nesbitt, H.W. \& Young, G.M. (1984). Prediction of some weathering trends of plutonic and volcanic rocks based on thermodynamic and kynetic considerations. Geochimica et Cosmochimica Acta, 48: 1523-1534. http://dx.doi.org/10.1016/0016-7037(84)90408-3.

Nogueira Neto, J.A. (2000). Evolução Geodinâmica das Faixas Granulíticas de Granja e Cariré, Extremo Noroeste da Província Borborema. PhD Thesis, Instituto de Geociências e Ciências Exatas da Universidade Estadual Paulista (IGCE-UNESP), Rio Claro, São Paulo, Brasil, 170 pp.

Otamendi, J.E. \& Patiño Douce, A.E. (2001). Partial melting of aluminous metagreywackes in the Northern Sierra de Comechingones, Central Argentina. Journal of Petrology, 42: 1751-1772. http://dx.doi.org/10.1093/ petrology/42.9.1751.

Pëto, P. (1976). An experimental investigation of melting reactions involving muscovite and paragonite in the silica saturated portion of the system $\mathrm{K}_{2} \mathrm{O}-\mathrm{Na}_{2} \mathrm{O}-$ $\mathrm{Al}_{2} \mathrm{O}_{3}-\mathrm{SiO}_{2}-\mathrm{H}_{2} \mathrm{O}$ to $15 \mathrm{kbar}$ total pressure. Programs in Experimental Petrology, Natural Environment Research Council 3rd report, 41-45.

Praxedes, I.F.; Silva, A.J.F.; Soares, W.C.; Magini, C.; Azevedo, M.R.; Nogueira Neto, J.A. \& Fuck, R.A. (2012). Idade de Anatexia do Complexo Granja, 
Domínio Médio Coreaú (DMC), Província Borborema (PB) - Dados Iniciais. Anais do $46^{\circ}$ Congresso Brasileiro de Geologia e $1^{\circ}$ Congresso de Geologia dos Países de Língua Portuguesa, Santos, Brasil.

Roser, B.P. \& Korsch, R.J. (1986). Discrimination of tectonic setting of sandstone-mudstone suites using $\mathrm{SiO}_{2}$ content and $\mathrm{K}_{2} \mathrm{O} / \mathrm{Na}_{2} \mathrm{O}$ ratio. Journal of Geology, 94: 635-650. http://dx.doi.org/10.1086/629071.

Roser, B.P. \& Korsch, R.J. (1988). Provenance Signatures of Sandstone-Mudstone suites determined using discriminant function analysis of major-element data. Chemical Geology, 67: 119-139. http://dx.doi. org/10.1016/0009-2541(88)90010-1.

Santos, T.J.S. (1993). Aspectos geológicos de uma área a sudeste de Granja, região NW do Ceará. M.Sc. Thesis, Instituto de Geociências e Ciências Exatas da Universidade Estadual Paulista (IGCE-UNESP), Rio Claro, São Paulo, Brasil, 159 pp.

Santos, T.J.S.; Fetter, A.H.; Hackspacher, P.C.; Van Schmus, W.R. \& Nogueira Neto, J.A. (2008). Neoproterozoic tectonic and magmatic episodes in the NW segment of the Borborema Province, NE Brazil, during the assembly of the western Gondwana. Journal of South American Earth Sciences, 25: 271-284. http://dx.doi. org/10.1016/j.jsames.2007.05.006.

Santos, T.J.S.; Fetter, A.H.; Van Schmus, W.R. \& Hackspacher, P.C. (2009). Evidence for 2.35 to $2.30 \mathrm{Ga}$ juvenile crustal growth in the northwest Borborema Province, NE Brazil In: Palaeoproterozoic Supercontinents and Global Evolution (Reddy, S.M.; Mazumder, R.; Evans, D.A.D.; Collins, A.S.; Eds.), Geological Society, London, Special Publications, 323: 271-281. http://dx.doi.org/10.1144/SP323.13.

Spear, F.S.; Kohn, M.J.; Cheney, J.T. (1999). P-T paths from anatectic pelites. Contributions to Mineralogy and Petrology, 134: 17-32. http://dx.doi.org/10.1007/ s004100050466.

Werner, C.D. (1987). Saxonian granulites: a contribution to the geochemical diagnosis of original rocks in high-metamorphic complexes. Gerlands Beitraege zur Geophysik, 96: 271-290. 